\title{
ANALISIS WACANA KRITIS PEMBERITAAN "AMIEN RAIS DIKOTOMIKAN PARTAI SETAN DAN PARTAI ALLAH" OLEH CNNINDONESIA.COM \\ (Critical Discourse Analysis on “Amien Rais's news Dichotomized the Satan Party and the God Party” by Cnnindonesia.com)
}

\author{
Khilmi Mauliddian \\ Magister Ilmu Linguistik, Fakultas Ilmu Budaya, Universitas Brawijaya \\ Jalan Veteran, Kota Malang, Kode Pos 65145 \\ Email: khilmi.mauliddian@gmail.com
}

(Naskah Diterima Tanggal 30 September-Direvisi Tanggal 5 Desember-Disetujui Tanggal 28 Desember)

\begin{abstract}
Amien Rais's news dichotomized the Satan party and the God party at the as news text posted on the Cnnindonesia.com news portal. This news text is important to be examined. The purpose of this research is to examine the diction that shows news of Amien Rais of the dichotomy between the Satan party and the God Party by the media. Data collection uses qualitative method with the critical discourse analysis approach or AWK Norman Fairclough so that text is displayed through a three-dimensional process i.e. textual analysis, practice discourtive and social practices. Textual dimension stage, theory analysis use diction selection theory of Gorys Keraf and the dominant data is obtained i.e. the dominance of diction at abstract words, concrete words, specific words, and foreign words. The data are then described, analyzed and linked to the interpretation of the preaching of the Cnnindonesia.com with the social conditions of the community. As for the interpretation of results found a recurring pattern of vocabulary and reassembled to affirm something by using the patterns vocabulary form a synonym or equivalent words.

Keywords: News, Amien Rais dichotomized the Satan party and the God party, Norman Fairclough, diction, interpretation
\end{abstract}

\begin{abstract}
Abstrak
Terdapat pemberitaan tentang Amien Rais yang mendikotomikan partai setan dan partai Allah sebagaimana pada teks berita yang dimuat pada portal berita Cnnindonesia.com. Teks berita ini penting untuk diteliti. Tujuan dari penelitian ini untuk mengetahui diksi yang menunjukkan pemberitaan Amien Rais tentang dikotomi partai setan dan partai Allah oleh media tersebut. Pengumpulan data dengan menggunakan metode kualitatif dengan pendekatan analisis wacana kritis atau AWK Norman Fairclough sehingga teks dipaparkan melalui proses tiga dimensi yakni analisis tekstual, praktik diskurtif, dan praktik sosial. Tahap dimensi tekstual, analisis teori menggunakan teori pemilihan diksi Gorys Keraf dan didapat hasil data yang dominan yaitu dominasi diksi pada kata abstrak, kata konkrit, kata khusus, dan kata asing. Data tersebut kemudian dideskripsikan, selanjutnya dianalisis dan dikaitkan dengan interpretasi pemberitaan dari Cnnindonesia.com dengan kondisi sosial masyarakat. Adapun hasil dari interpretasi ditemukan pola kosakata yang berulang dan disusun kembali untuk menegaskan sesuatu dengan menggunakan pola kosakata bentuk sinonim atau padanan kata.
\end{abstract}

Kata Kunci: pemberitaan, Amien Rais dikotomikan partai setan dan partai Allah, Norman Fairclough, diksi, interpretasi 


\section{PENDAHULUAN}

Penyampaian informasi dengan menggunakan media internet kini semakin banyak. Pola penyebaran berita juga lebih mudah karena media berita online juga menggunakan media jejaring sosial sebagai media penyebarannya. Masyarakat semakin dimudahkan dalam mengonsumsi berita dari media online yang diinginkan. Dengan menekan laman suatu media online yang diinginkan, hasilnya berita media bisa dinikmati.

Sejalan dengan fenomena perkembangan teknologi pada media informasi khususnya berita, berita hingga saat ini masih dianggap oleh masyarakat sebagai kontruksi peristiwa yang mewakili dari apa yang ada dalam masyarakat. Dengan adanya berita, masyarakat akan tahu berbagai macam informasi yang terjadi baik sekala lokal maupun sekala internasional. Adapun berita sendiri akan bisa diterima oleh masyarakat apabila menggunakan media bahasa dalam penyebaran informasinya. Dengan demikian, bahasa sebagai media penyampai informasi masih merupakan sarana efektif agar maksud penyampaiannya bisa diterima oleh masyarakat.

Bahasa dalam media adalah dua sisi yang tidak bisa dipisahkan. Richardson (2007: 6) menyatakan bahwa " the language used in newspaper is one key site in naturalisasion of in qequality and neutralisasion of dissert". Media tanpa bahasa maka suatu media tidak akan bisa menyebarkan informasi yang diinginkannya. Sedangkan Fairclough (1989) menyatakan bahwa bahasa merupakan media untuk mengungkapkan ide, gagasan, dan pikiran juga perasaan. Namun pada kenyataannya bahasa dalam media seiring waktu juga berubah. Perubahan ini ditandai dengan pemanfaatan media dalam hal tertentu, yaitu bahasa saat ini telah menjadi media perantara dalam pelaksanaan kuasa melalui ideologi. Bahkan bahasa juga menyumbang proses dominasi terhadap orang lain oleh pihak lain (Fairclough, 1989:2).

Sejalan dengan pernyataan di atas, Halliday (dalam Mayasari, 2013: 2) juga menegaskan bahwa sesungguhnya bahasa bukan hanya terdiri atas kalimat, melainkan juga terdiri atas teks atau wacana yang di dalamnya terdapat tukar-menukar maksud dalam konteks interpersonal antara satu dengan yang lain.

Konteks dalam tukar menukar maksud itu tidak bersifat kosong dari nilai sosial, tetapi sangat dipengaruhi oleh konteks sosial budaya masyarakatnya. Salah satu bidang yang juga memanfaatkan bahasa dalam kaitannya dengan pelaksanaan kuasa dalam ideologi seperti yang dijelaskan di atas adalah bidang media itu sendiri. Sebagian besar bentuk produksi media diwujudkan dalam bentuk bahasa. Pemanfaatan bahasa yang saat ini mendominasi media adalah penggunaan bahasa dalam merepresentasikan sesuatu. Sesuatu dapat direpresentasikan sedemikian rupa oleh media sehingga menghadirkan sebuah sudut pandang yang berbeda. Fairclough mengatakan bahwa untuk menemukan "realitas" di balik teks diperlukan penelusuran atas konteks produksi teks, konsumsi teks, dan aspek sosial budaya yang mempengaruhi pembuatan teks. Dikarenakan penulisan sebuah teks tidak lepas akan kepentingan yang bersifat subjektif.

Sehubungan dengan aspek kebahasaan dalam mempresentasikan tokoh ideologi dalam pemberitaan, teks berita merupakan sarana paling efektif untuk melihat bagaimana pemakai bahasa membawa nilai ideologi tertentu dalam menghasilkan berita. Terlebih teks berita apabila menyangkut salah satunya pada wacana politik atau wacana kekuasaan. Wacana politik akan 
terjadi seiring kondisi politik sedang mengalami dinamis. Salah satu pemberitaan politik yang tengah terjadi terkait kontroversi dikotomi kata Partai Allah dan Partai Setan dari pernyataan Amin Rais. Pernyataan itu menjadi kontroversi karena hampir setiap media memberitakan. Sehingga masyarakat menjadi heboh akan pernyataan tersebut setelah membaca berita,

Pernyataan yang dianggap kontroversi yang disebutkan di atas bermula saat Amien Rais mengisi ceramah di masjid Baiturrahim, Mampang Prapatan, Jakarta Selatan, usai mengikuti Gerakan Indonesia Salat Subuh berjemaah Jumat (13/4) pagi (cnnindonesia.com). Ia mengatakan bahwa partai-partai politik di Indonesia jadi dua kutub yakni partai setan dan partai Allah. Kemudian dengan sigap media pemberitaan seperti cetak, radio, televisi, online baik lokal maupun nasional bergegas membuat berita dan segera menyebarkan informasi pernyataan Amien Rais ini ke tengah masyarakat. Pernyataan ini lantas membuat heboh publik, sehingga pro dan kontrapun terjadi di tengah masyarakat.

Pemberitaan tentang pernyataan Amien Rais sebenarnya hanyalah ungkapan yang biasa saja. Namun, berhubung Amin Rais adalah tokoh nasional dan secara rekam jejak adalah seorang politisi dan pendiri partai maka pernyataan itu menjadi luar biasa dan menjadi bahan berita yang renyah oleh media. Salah satu media yang memberitakannya adalah media online Cnnindonesia.com dengan judul berita "Amien Rais Dikotomikan Partai Setan dan Partai Allah". Berita tersebut diterbitkan Jumat, 13 April 2018.

Berita yang disajikan oleh cnnindonesia.com di atas sangat menarik untuk dikaji. Sebab secara langsung dengan melihat judul berita yang diterbitkan Cnnindonesia.com seolah-olah membuat opini untuk 'menghakimi' dengan membuat judul berita dengan menyebut nama orang langsung. Oleh sebab itu, dengan latar belakang yang telah dijabarkan di atas peneliti ingin memfokuskan penelitian dengan judul "Pemberitaan "Amien Rais Dikotomikan Partai Setan dan Partai Allah" oleh Cnnindonesia.com."

Penelitian terkait pemberitaan dalam ranah bidang tertentu sudah dilakukan. Mardikantoro (2014) telah melakukan penelitian mengenai analisis wacana kritis pada wacana korupsi pada tajuk media massa. Dari hasil penelitian tersebut diperoleh dua hasil penelitian, pertama dengan bingkai mengkritisi berita korupsi, koran Tempo dengan dua tajuknya menyatakan ketidaksetujuannya terhadap berita korupsi. Kedua dengan bingkai mendukung berita korupsi, surat kabar Kompas, Republika, Jawa Pos, dan Suara Merdeka menyatakan kesetujuannya dalam mendukung berita korupsi di surat kabar. Titik pangkal pada penelitian ini lebih terfokus pada aspek komunikasi berita, sehingga analisis penelitian berfokus pada maksud dari informasi yang dihasilkan oleh media pemberitaan.

Dengan demikian, berdasarkan hasil penelitian terdahulu, maka peneliti akan memfokuskan pada bentuk wacana politik yang diberitakan oleh Cnnindonesia.com dengan mendasarkan informasi berita dari pernyataan tokoh. Adapun perbedaan dengan penelitian ini dengan terdahulu terletak pada ruang lingkup yang dikaji yaitu berdasarkan atas struktur bahasa dari berita Cnnindonesia.com yang digunakan sebagai media penyampai informasi berita.

Adapun dalam penelitian ini terdapat dua masalah pokok yang menjadi kajian. Pertama, bagaimanakah diksi yang menunjukkan pemberitaan "Amien Rais dikotomikan partai setan dan partai Allah" Oleh Cnnindonesia.com? sedangkan yang kedua, Mengapa diksi dibuat dalam pemberitaan pemberitaan "Amien Rais 
dikotomikan partai setan dan partai Allah" Oleh Cnnindonesia.com?

Sehubungan dengan rumusan masalah di atas, dalam penelitian ini terdapat dua tujuan, antara lain; pertama, mengetahui diksi yang menunjukkan pemberitaan pemberitaan "Amien Rais dikotomikan partai setan dan partai Allah" Oleh Cnnindonesia.com. sedangkan kedua, Mengetahui alasan pemilihan kata atau diksi pada pemberitaan pemberitaan "Amien Rais dikotomikan partai setan dan partai Allah" Oleh Cnnindonesia.com.

Seperti yang dijelaskan dalam latar belakang di atas, fokus penelitian ini berdasarkan pada sebuah berita yang dibuat dan disebarkan oleh portal berita Cnnindonesia.com. Menurut Assegaf (1991:179), pengertian definisi berita dalam teknis jurnalistik adalah laporan tentang fakta atau ide yang dipilih oleh staf redaksi suatu harian untuk disiarkan, yang dapat menarik perhatian pembaca, bisa jadi karena luar biasa, bisa karena pentingnya atau akibatnya, bisa pula karena ia mencakup segi-segi human interest seperti humor, emosi dan ketegangan.

Menurut Bruce dan Douglas (dalam Junaedi 2007: 22), dalam menulis berita wartawan atau reporter mengacu kepada unsur pokok berita atau sering disebut sebagai rumus umum penulisan sebuah berita. Unsur pokok berita tersebut dikenal dengan $5 \mathrm{~W}+1 \mathrm{H}$, kependekan dari: 1 . What : Apa yang terjadi 2. Where : Dimana hal itu terjadi 3. When : Kapan peristiwa itu terjadi 4. Why: Kenapa peristiwa itu terjadi 5. Who : Siapa yang terlibat dalam kejadian itu 6 . How : Bagaimana peristiwa itu terjadi.

Ada beberapa faktor yang mendasari derajat nilai berita yang layak dipublikasikan (newsworthiness), ukuran yang dipakai oleh wartawan adalah ukuran-ukuran professional yang dinamakan sebagai nilai berita seperti yang dikutip Assegaff (dalam Romli 2002:2) adalah "laporan tentang suatu kejadian yang dapat menarik perhatian khalayak pembaca". Sedangkan nilai-nilai berita yang layak dipublikasikan menurut Djuraid (2007: 1144) meliputi: 1) aktual, (2) kedekatan, (3) penting, (4) luar biasa, (5) tokoh, (6) eksklusif, (7) ketegangan, (8) konflik, (9) human interest, (10) seks, (11) progresif, (12) trend, (13) humor.

Penelitian ini pada hakikatnya meneliti berita yang dibuat dan disampaikan oleh media online cnnindonesia.com. Media berita online merupakan portal berita yang disajikan dalam bentuk digital dengan menggunakan internet sebagai sarana menyampaikan informasi. Menurut Ashadi Siregar (dalam Kurniawan, 2005: 20) media online adalah sebutan umum untuk sebuah bentuk media yang berbasis telekomunikasi dan multimedia (baca-komputer dan internet). Di dalamnya terdapat portal, website (situs web), radio-online, TV-online, pers online, mail-online, dengan karakteristik masing-masing sesuai dengan fasilitas yang memungkinkan user memanfaatkannya. Media online termasuk kategori generasi baru dalam dunia pemberitaan. Seperti halnya dengan $\mathrm{CNN}$ Indonesia, dengan memanfaatkan media online, kantor berita tersebut memanfaatkan media online dengan menggunakan alamat portal berita cnnindonesia.com sebagai media penyebaran beritanya. Sedangkan sejarah berdirinya cnnindonesia.com berdasarkan dari wikipedia.com merupakan Cable News Network Indonesia (disingkat CNN Indonesia). Cnnindonesia.com diluncurkan pada 20 Oktober 2014, portal berita ini merupakan milik Trans Media yang bekerjasama dengan $\underline{\text { Turner }}$ International.

Analisis wacana kritis atau Critical Discourse Analysis yang biasa disingkat AWK dalam bahasa Indonesia, wacana di sini tidak dipahami semata sebagai studi bahasa. Pada akhirnya, analisis wacana memang menggunakan bahasa dalam teks 
untuk dianalisis, tetapi bahasa yang dianalisis di sini agak berbeda dengan studi bahasa dalam pengertian linguistik tradisional. Bahasa dianalisis bukan dengan menggambarkan semata dari aspek kebahasaan, tetapi juga menghubungkan dengan konteks. Konteks di sini berarti bahasa itu dipakai untuk tujuan praktik tertentu, termasuk di dalamnya praktik kekuasaan (Eriyanto, 2001: 7). Mengutip Fairclough dan Wodak, AWK menyelidiki bagaimana melalui bahasa kelompok sosial yang ada saling bertarung dan mengajukan versinya masing-masing (Eriyanto, 2001: 78). Dalam AWK Norman Fairclough mengemukakan bahwa wacana merupakan sebuah praktik sosial dan membagi analisis wacana dalam tiga dimensi, yaitu Teks, Discourse Practice, dan Sosciocultural Practice (Darma, 2009:49-56).

Untuk menganalisis teks maka langkah pertama yang dilakukan adalah teks dianalisis secara linguistik, dengan melihat bentuk atau tata kalimat, kosakata, semantik. Pada analisis ini akan berfokus pada pilihan kata atau diksi. Kemudian langkah kedua dengan menekankan dimensi yang berhubungan dengan proses produksi dan konsumsi teks sebagai latar belakang munculnya teks tersebut. Pada dimensi kedua proses interprestasi juga muncul dimana pembaca mengonsumsi dan memaknai dari teks tersebut. Kemudian yang ketiga adalah dimensi Sociocultural Practice yaitu dimensi yang berhubungan dengan konteks di luar teks dan konteks, disini memasukkan banyak hal, seperti konteks situasi, lebih luas adalah konteks dari praktik institusi dari media sendiri dalam hubungannya dengan struktur atau kondisi sosial.

Untuk memahami teori AWK Fairclough sebagai langkah dalam penelitian ini harus memahami mengenai diksi dari teks berita. Pengertian pilihan kata atau diksi jauh lebih luas dari apa yang dipantulkan oleh jalinan kata-kata itu. Istilah ini bukan saja dipergunakan untuk menyatakan katakata mana yang dipakai untuk mengungkapkan suatu ide atau gagasan, tapi juga meliputi persoalan fraseologi, gaya bahasa, dan ungkapan. Fraseologi mencakup persoalan kata-kata dalam pengelompokan atau susunannya, atau yang menyangkut cara-cara yang khusus berbrntuk ungkapanungkapan. Gaya bahasa sebagai bagian dari diksi berkaitan dengan ungkapan-ungkapan yang individual atau karakteristik, atau yang memiliki nilai artistik yang tinggi.

Menurut Widyamartaya (1990: 45) diksi atau pilihan kata adalah kemampuan seseorang membedakan secara tepat nuansanuansa makna sesuai dengan gagasan yang ingin disampaikannya, dan kemampuan tersebut hendaknya disesuaikan dengan situasi dan nilai rasa yang dimiliki sekelompok masyarakat dan pendengar atau pembaca. Dalam penelitian ini fokus diksi didasarkan pada jenis kelompok diksi menurut menurut Keraf, (1996: 89-108) adalah sebagai berikut.

a. Denotasi adalah konsep dasar yang didukung oleh suatu kata (makna itu menunjuk pada konsep, referen, atau ide).

b. Konotasi adalah suatu jenis makna kata yang mengandung arti tambahan, imajinasi atau nilai rasa tertentu. Konotasi merupakan kesan-kesan atau asosiasiasosiasi, dan biasanya bersifat emosional yang ditimbulkan oleh sebuah kata di samping batasan kamus atau definisi utamanya.

c. Kata abstrak adalah kata yang mempunyai referen berupa konsep, kata abstrak sukar digambarkan karena referensinya tidak dapat diserap dengan pancaindera manusia. Kata-kata abstrak merujuk kepada kualitas (panas, dingin, baik, buruk), pertalian (kuantitas, jumlah, tingkatan), dan pemikiran (kecurigaan, penetapan, kepercayaan). Kata-kata 
abstrak sering dipakai untuk menjelaskan pikiran yang bersifat teknis dan khusus.

d. Kata konkret adalah kata yang menunjuk pada sesuatu yang dapat dilihat atau diindera secara langsung oleh satu atau lebih dari pancaindera. Katakata konkrit menunjuk kepada barang yang actual dan spesifik dalam pengalaman. Kata konkrit digunakan untuk menyajikan gambaran yang hidup dalam pikiran pembaca melebihi kata-kata yang lain.

e. Kata umum adalah kata yang mempunyai cakupan ruang lingkup yang luas, katakata umum menunjuk kepada banyak hal, kepada himpunan, dan kepada keseluruhan.

f. Kata khusus adalah kata-kata yang mengacu kepada pengarahanpengarahan yang khusus dan konkrit. Kata khusus memperlihatkan kepada objek yang khusus.

g. Kata ilmiah adalah kata yang dipakai oleh kaum terpelajar, terutama dalam tulisantulisan ilmiah.

h. Kata populer adalah kata-kata yang umum dipakai oleh semua lapisan masyarakat, baik oleh kaum terpelajar atau oleh orang kebanyakan.

i. Jargon adalah kata-kata teknis atau rahasia dalam suatu bidang ilmu tertentu, dalam bidang seni, perdagangan, kumpulan rahasia, atau kelompokkelompok khusus lainnya.

j. Kata slang adalah kata-kata non standard yang informal, yang disusun secara khas, bertenaga dan jenaka yang dipakai dalam percakapan, kata slang juga merupakan kata-kata yang tinggi atau murni.

k. Kata asing ialah unsur-unsur yang berasal dari bahasa asing yang masih dipertahankan bentuk aslinya karena belum menyatu dengan bahasa aslinya.

1. Kata serapan adalah kata dari bahasa asing yang telah disesuaikan dengan wujud atau struktur bahasa Indonesia.
Dari jenis kelompok diksi di atas, maka dapat disimpulkan ada 12 jenis diksi yang digunakan sebagai dasar pengelompokan kata pada penelitian ini.

\section{METODE PENELITIAN}

Analisis data berdasarkan AWK dilakukan dengan metode kualitatif Fairclough (1995) yang memandang wacana sebagai teks. Menurut Moleong penelitian kualitatif adalah penelitian yang tidak menggunakan prosedur statistik tetapi menggunakan prosedur deskriptif sebagai data atas hasil dari yang diamati (2005:6). Hal ini bahasa dalam media massa dipandang sebagai rekontruksi dari penulis berita. Pendekatan yang digunakan dalam penelitian ini adalah pendekatan AWK. Menurut Badara (2012: 26) AWK yaitu suatu pengkajian secara mendalam yang berusaha mengungkap kegiatan, pandangan, dan identitas berdasarkan bahasa yang digunakan dalam wacana.

Adapun pendekatan kritis dalam memandang bahasa dianggap selalu terlibat dalam hubungan kekuasaan, terutama dalam membentuk subjek serta berbagai tindakan representasi yang terdapat dalam masyarakat. Analisis wacana kritis yang juga menggunakan pendekatan kritis menganalisis bahasa tidak saja dari aspek kebahasaan, tetapi juga menghubungkannya dengan konteks. Konteks yang dimaksud adalah untuk tujuan dan praktik tertentu. Oleh sebab itu, dengan melalui wacana kritis, peneliti mencoba untuk menelisik dan membedah lebih lanjut bagaimana Cnnindonesia.com mengontruksi berita politik. 
Data dalam penelitian ini berasal dari bentuk kosakata yang mendikotomisasi dalam berita cnnindonesia.com. Sedangkan sumber data adalah berita yang diambil dari media online Cnnindonesia.com dengan judul berita "Amien Rais Dikotomikan Partai Setan dan Partai Allah". Berita tersebut diterbitkan Jumat, 13 April 2018. Adapun metode pengumpulan data menurut Mahsun (2014) dibagi menjadi dua, yaitu metode simak dan metode cakap. Dalam penelitian ini menggunakan metode simak bebas, yaitu simak dan catat.

Sedangkan metode analisis data yang digunakan berupa analisis yang disesuaikan dengan perspektif AWK Fairclough. Dalam perspektif Fairclough (1992:109) terdapat tiga tahap analisis, yaitu deskripsi, interpretasi, dan eksplanasi. Tahap deskripsi yaitu menguraikan isi dan analisis deskriptif dari wacana. Pada tahap ini teks dijelaskan tanpa dihubungkan dengan aspek lain, hanya menganalisis kosakata, tata bahasa, dan struktur teks. Tahap interpretasi yaitu dengan menafsirkan teks yang dihubungkan dengan praktik wacana yang dilakukan. Tahap terakhir tahap eksplanasi, yaitu bertujuan untuk mencari penjelasan dan hasil penafsiran yang diperoleh pada tahap interpretasi untuk menemukan alasan mengapa teks berita tersebut diproduksi.

\section{PEMBAHASAN}

Pada bagian ini akan dipaparkan hasil analisis wacana kritis. Dalam analisis ini, dimensi tekstual dengan perpektif analisis wacana kritis Norman Fairclough meliputi uraian kosakata, gramatika, dan struktur tekstual. Sedangkan aspek kosakata, ada beberapa kosakata yang dipakai dalam mempresentasikan.

\section{Dimensi Tekstual}

\section{Diksi Berdasarkan pada Langsung Tidaknya Makna}

Sebelum menganalisis diksi, maka langkah pertama adalah menganalisis bentuk kalimat atau tata kalimat dalam teks pemberitaan Amien Rais dalam Cnnindonesia.com. Berdasarkan bentuk kalimatnya, jenis kalimat dibagi menjadi dua yaitu kalimat langsung atau dan kalimat tak langsung. Pada struktur teks pemberitaan Cnnindonesia.com terdiri dalam bentuk 16 kalimat dan terbagi menjadi kalimat langsung dan tak langsung. Berikut bentuk kalimat disajikan dalam tabel 1. di bawah ini.

Tabel 1. Kalimat Langsung dan Tak Langsung

\begin{tabular}{|l|l|l|}
\hline No. & Kalimat & Bentuk Kalimat \\
\hline 1. & $\begin{array}{l}\text { Ketua Penasihat Persaudaraan Alumni 212 Amien Rais } \\
\text { mendikotomikan partai-partai politik di Indonesia jadi dua kutub } \\
\text { yakni partai setan dan partai Allah. }\end{array}$ & Tak Langsung \\
\hline 2. & $\begin{array}{l}\text { "Sekarang ini kita harus menggerakkan seluruh kekuatan bangsa ini } \\
\text { untuk bergabung dan kekuatan dengan sebuah partai. Bukan hanya } \\
\text { PAN, PKS, Gerindra, tapi kelompok yang membela agama Allah, } \\
\text { yaitu hizbullah. Untuk melawan siapa? untuk melawan hizbusy } \\
\text { syaithan," }\end{array}$ & $\begin{array}{l}\text { "Onang-orang yang anti Tuhan, itu otomatis bergabung dalam partai } \\
\text { besar, itu partai setan. Ketahuilah partai setan itu mesti dihuni oleh } \\
\text { orang-orang yang rugi, rugi dunia rugi akhiratnya... Tapi di tempat } \\
\text { lain, orang yang beriman bergabung di sebuah partai besar namanya } \\
\text { hizbullah, Partai Allah. Partai yang memenangkan perjuangan dan } \\
\text { memetik kejayaan," }\end{array}$ \\
\hline
\end{tabular}




\begin{tabular}{|c|c|c|}
\hline 4. & $\begin{array}{l}\text { Saat dikonfirmasi usai memberikan tausiyah, Amien enggan } \\
\text { membeberkan partai apa saja yang masuk kategori hizbus syaithan }\end{array}$ & Tak Langsung \\
\hline 5. & $\begin{array}{l}\text { "Saya enggak katakan begitu. Jadi bukan partai, tapi cara berpikir. } \\
\text { Cara berpikir yang untuk Allah dan yang diikuti oleh setan. } \\
\text { Gelombang pro setan merugi, gelombang besar yang didikte } \\
\text { kehendak Allah pasti menang," }\end{array}$ & Langsung \\
\hline 6. & $\begin{array}{l}\text { Dalam tausiyahnya, Amien yang juga mantan Ketua Umum PP } \\
\text { Muhammadiyah dan Ketua Dewan Kehormatan Partai Amanat } \\
\text { Nasional (PAN) mengatakan perubahan suatu negara tak lepas dari } \\
\text { perubahan politik. }\end{array}$ & Tak Langsung \\
\hline 7. & $\begin{array}{l}\text { Dengan kata lain, ia menegaskan politik adalah panglima dalam } \\
\text { perubahan. }\end{array}$ & Tak Langsung \\
\hline 8. & $\begin{array}{l}\text { "Perubahan ekonomi, perubahan pendidikan, penegakan hukum, } \\
\text { penegakan akhlak, dan lain-lain itu tergantung kepada kekuasaan } \\
\text { politik itu," }\end{array}$ & Langsung \\
\hline 9. & $\begin{array}{l}\text { Perubahan kekuasaan politik di Indonesia, tegas dia, harus } \\
\text { diperjuangkan mulai saat ini. }\end{array}$ & Tak Langsung \\
\hline 10. & $\begin{array}{l}\text { "It's now or never (sekarang atau tidak sama sekali). Tomorrow, next } \\
\text { year, will be too late (esok, tahun depan, sudah terlambat). Jadi tahun } \\
\text { depan ini adalah penentuan yang lebih meyakinkan lagi. Kalau kita } \\
\text { biarkan kekuasaan hizbusy syaithan, setan enggak pernah bisa } \\
\text { kompromi," }\end{array}$ & Langsung \\
\hline 11. & $\begin{array}{l}\text { Dalam tausiyahnya Amien juga mengkritik pernyataan Presiden } \\
\text { Jokowi di Sibolga, Sumatera Utara soal pemisahan agama dari politik. }\end{array}$ & Langsung \\
\hline 12. & $\begin{array}{l}\text { "Ini presiden yang ilmunya pas-pasan... Sehingga kemudian memang } \\
\text { untuk merekonstruksi bangsa kita ini, harus mulai dari rekonstruksi } \\
\text { pimpinannya," }\end{array}$ & Langsung \\
\hline 13. & $\begin{array}{l}\text { Usai tausiyah, Amien menerangkan ada fakta gerakan 'Ganti Presiden } \\
\text { tahun 2019' menyebar di Indonesia. }\end{array}$ & Tak Langsung \\
\hline 14. & $\begin{array}{l}\text { Ia mengklaim dari kelas bawah, menengah, guru, hingga pegawai } \\
\text { telah terpapar itu. }\end{array}$ & Tak Langsung \\
\hline 15. & $\begin{array}{l}\text { "Terjadi karena Allah menghendaki, sebagai orang beragama yakin } \\
\text { bahwa kekuasaan sepenuhnya di tangan Allah," }\end{array}$ & Langsung \\
\hline 16. & $\begin{array}{l}\text { "Allah memberikan kekuasaan bagi siapapun yang dikehendaki, akan } \\
\text { mencabut kembali dari siapapun yang dikehendaki. Saya tidak boleh } \\
\text { mendahului takdir Allah, tapi prediksi boleh. Memang pamor pak } \\
\text { Jokowi secara sistematik merosot terus," }\end{array}$ & Langsung \\
\hline
\end{tabular}

Berdasarkan jumlah pola kalimat dalam tabel di atas, struktur teks pemberitaan Amien Rais terbagi dalam dua pola kalimat, yakni sebanyak 9 kalimat berbentuk kalimat langsung, dan 7 kalimat berbentuk kalimat tak langsung.

Dari paparan tabel bentuk kalimat di atas, berdasarkan diksi, terdapat beberapa kalimat yang berbentuk denotasi dan konotasi.

Data 1

"Ketua Penasihat Persaudaraan Alumni 212

Amien Rais mendikotomikan partai-partai politik di Indonesia jadi dua kutub yakni partai setan dan partai Allah". (Kalimat 1)

Berdasarkan data kalimat 1 di atas, kalimat tersebut memiliki dua bentuk pola kalimat yaitu denotasi dan konotasi. Bentuk kalimat denotasi terdapat pada kalimat Ketua Penasihat Persaudaraan Alumni 212 Amien Rais mendikotomikan partai-partai politik di Indonesia jadi dua kutub yakni merupakan kalimat tidak langsung namun memiliki makna denotasi, maksudnya adalah kalimat ini tanpa dijelaskan bisa dipahami maknanya 
karena memiliki struktur yang jelas yaitu Subjek + Predikat+Objek.

Sedangkan kalimat pada partai setan dan partai Allah adalah bentuk frasa yang bermakna konotasi. Dimana frasa tersebut tidak memberikan penjelasan secara langsung sehingga sulit dimengerti sehingga memiliki arti yang tidak sebenarnya. Merujuk pada frasa tersebut apabila diterangkan maksud dari konotasi mempunyai makna bahwa partai di Indonesia terbagi menjadi dua, yaitu partai dengan kiasan setan sebagai partai yang buruk dan partai dengan kiasan kata Allah sebagai partai yang baik.

$\underline{\text { Data II }}$

"Ini presiden yang ilmunya pas-pasan... Sehingga kemudian memang untuk merekonstruksi bangsa kita ini, harus mulai dari rekonstruksi pimpinannya," (kalimat 12)

Berdasarkan kalimat 12, kalimat Ini presiden yang ilmunya pas-pasan... merupakan kalimat denotatif namun memiliki makna konotatif. Berdasarkan struktur kalimatnya, kalimat tersebut memiliki pola lengkap (Subjek+Predikat+Keterangan Sifat). Namun pada struktur keterangan sifat frasa ilmunya pas-pasan memiliki makna konotatif dimana frasa tersebut bukan makna sebenarnya atau kiasan. Sehingga ini menimbulkan penafsiran dalam memahami makna kalimat tersebut. Makna konotasi ilmunya pas-pasan bisa digambarkan sebagai ungkapan bahwa presiden indonesia kurang mempunyai kepandaian.

\section{Diksi Berdasarkan Ada tidaknya Referen}

Diksi berdasarkan ada tidaknya referen dibagi menjadi dua yaitu kata abstrak yang berarti sukar digambarkan oleh pancaindera, dan kata konkrit yang bisa dirasakan oleh panca indera. Berikut di bawah ini tabel 2 yang menunjukkan diksi abstrak sebagai data III

Tabel 2. Kata abstrak

\begin{tabular}{|l|l|l|}
\hline Kata Abstrak & Kalimat & Keterangan \\
\hline Politik & 1 & $\begin{array}{l}\text { Kata benda yang menunjukkan tentang cara } \\
\text { berkuasa. }\end{array}$ \\
\hline Partai Setan & 1 & Kata benda yang diyakini tapi tidak berwujud \\
\hline Partai Allah & 1 & Kata benda yang diyakini tapitidak berwujud \\
\hline Kekuatan & 2 & Kata benda yang menunjukkan gaya \\
\hline Agama & 2 & $\begin{array}{l}\text { Kata benda yang menggambarkan keyakinan } \\
\text { yang hanya bisa dirasakan }\end{array}$ \\
\hline anti Tuhan & 3 & $\begin{array}{l}\text { Kata benda yang merujuk } \\
\text { ketidaksetujuan } \\
\text { terhadap Tuhan }\end{array}$ \\
\hline Akhiratnya & 3 & Kata benda yang diyakini tapi tidak berwujud \\
\hline Perjuangan & 3 & $\begin{array}{l}\text { Kata kerja yang berarti pengorbanan dan } \\
\text { hanya bisa dirasakan }\end{array}$ \\
\hline Kejayaan & 3 & Kata benda yang menggambarkan perasaan. \\
\hline Cara berpikir & 5 & Kata kerja yang hanya bisa dirasakan. \\
\hline Kekuasaan & 9 & $\begin{array}{l}\text { Kata benda yang menggambarkan suatu hal } \\
\text { yang mutlak dimiliki secara penuh }\end{array}$ \\
\hline Pas-pasan & 12 & Kata sifat yang menggambarkan perasaan \\
\hline
\end{tabular}


Suar Bétang, Vol.13, No.2, Edisi Desember, 2018: 193-205

\begin{tabular}{|l|l|l|}
\hline Mengklaim & 14 & $\begin{array}{l}\text { Kata kerja yang menggambarkan sikap untuk } \\
\text { memiliki atas dasar keyakinan sendiri }\end{array}$ \\
\hline Kelas bawah & 14 & $\begin{array}{l}\text { Kata benda yang menggambarkan kondisi } \\
\text { sosial }\end{array}$ \\
\hline Beragama & 15 & $\begin{array}{l}\text { Kata kerja yang menunjukkan sikap terhadap } \\
\text { suatu keyakinan atau jalan hidup manusia }\end{array}$ \\
\hline Takdir & 16 & Kata benda yang menggambarkan nasib \\
\hline Prediksi & 16 & $\begin{array}{l}\text { Kata kerja yang menggambarkan tentang } \\
\text { suatu hal }\end{array}$ \\
\hline Pamor & 16 & $\begin{array}{l}\text { Kata benda yang menggambarkan kondisi } \\
\text { yang sedang banyak dibicarakan }\end{array}$ \\
\hline
\end{tabular}

Selanjutnya kata konkrit juga ditemukan dalam teks berita tersebut. Berikut data kongkret yang dalam hal ini menujukkan sesuatu yang bisa dilihat, diraba, dicium, didengar oleh pancaindera. Data kongkret tidak memerlukan penjelasan lagi karena sudah bisa pahami secara jelas maknanya. Berikut data disajikan dalam tabel 3 sebagai data IV

$\underline{\text { Data IV }}$

Tabel 3 kata konkrit

\begin{tabular}{|l|l|l|}
\hline Kata Kongkret & Kalimat & Keterangan \\
\hline Partai-partai & 1 & Kb jamak \\
\hline Mendikotomikan & 1 & Kk (membagi) \\
\hline Dua kutub & 1 & Frasa pembagian \\
\hline Menggerakkan & 2 & $\mathrm{Kk}$ \\
\hline Bergabung & 2 & $\mathrm{Kk}$ \\
\hline Kelompok & 2 & $\mathrm{~Kb}$ \\
\hline Membela & 2 & $\mathrm{Kk}$ \\
\hline Beriman & 2 & $\mathrm{Kk}$ \\
\hline Melawan & 2 & $\mathrm{Kk}$ \\
\hline Gelombang & 5 & $\mathrm{~Kb}$ \\
\hline Pro & 5 & $\mathrm{~Kb}$ \\
\hline Merugi & 5 & $\mathrm{Kk}$ \\
\hline Didekte & 5 & $\mathrm{Kk} \mathrm{pasif}$ \\
\hline Perubahan & 6,8 & $\mathrm{Kk}$ \\
\hline Panglima & 7 & $\mathrm{~Kb}$ \\
\hline Penegakan & 8 & $\mathrm{Kk}$ \\
\hline Penentuan & 10 & $\mathrm{Kk}$ \\
\hline Kompromi & 10 & $\mathrm{Ks}$ \\
\hline Presiden & 12 & $\mathrm{~Kb}$ \\
\hline Merekontruksi & 12 & $\mathrm{Kk}$ \\
\hline Merosot & 16 & $\mathrm{Kk}$ \\
\hline
\end{tabular}

\section{Diksi Berdasarkan Luas Cakupan}

Diksi berdasarkan luas cakupan dibagi menjadi dua, yaitu kata umum dan kata khusus. Kata umum berarti mempunyai arti lebih luas, sedangkan kata khusus mempunyai arti lebih sempit. Kata yang ditemukan dalam teks berita ini adalah kata institusi, istilah keagamaan, dan macammacam kata kerja berafiliasi dengan istilah politik. 
Data V

Kata khusus dalam istilah geografi :

1. Masjid Baiturrahim, 2. Mampang 3. Prapatan, 4. Jakarta selatan 5. Indonesia, 6. Sumatera Barat, 7. Sibolga.

Data VI

Kata khusus dalam istilah keagamaan :

1. Tausyiah

2. Hizbullah

3. Hizbusyaithon

Kata khusus yang yang berafiliasi dengan makna dikotomi pada judul berita :

Dikotomi sama halnya dengan dua kutub, partai-partai, kelompok, beriman, anti Tuhan, Pro.

\section{Diksi berdasarkan Pengguna}

Diksi yang hanya dimengerti oleh beberapa kalangan tertentu. Ada beberapa kata yang yang menggunakan istilah kata ilmiah, asing, dan serapan.

Data VI

Diksi istilah Ilmiah .tapi prediksi boleh. Memang pamor pak Jokowi secara sistematik merosot terus," (kalimat 16)

Penggunaan diksi sistematis pada kalimat 16 merupakan bentuk penggunaan istilah ilmiah. Sistematik memiliki pengertian runtut atau terarah.

Diksi istilah asing.

“.......kelompok yang membela agama Allah, yaitu hizbullah. Untuk melawan siapa? untuk melawan hizbusy syaithan," (kalimat 2)

"It's now or never (sekarang atau tidak sama sekali). Tomorrow, next year, will be too late (esok, tahun depan, sudah terlambat). Jadi tahun depan ini adalah penentuan yang lebih meyakinkan lagi. Kalau kita biarkan kekuasaan hizbusy syaithan, setan enggak pernah bisa kompromi," Kalimat 10
Penggunaan kata hizbullah dan hizbusy syaithan, kalimat 2 dan kata "It's now or never, Tomorrow, next year, will be too late dalam kalimat 10 merupakan bentuk penggunaan bahasa asing. Bahasa asing yang dimaksud pada kalimat dua adalah bahasa arab yang berarti kelompok Allah dan kelompok setan. Sedangkan pada kalimat 1o menggunakan bahasa Inggris namun dalam berita tersebut diberikan terjemahan sehingga pembaca yang tidak paham bahasa Inggris bisa langsung memahami.

\section{a. Praktik Diskursif}

Ditengah maraknya pemberitaan mengenai istilah partai setan dan partai Allah, cnnindonesia.com merupakan salah satu media yang turut memberitakan dengan gaya bahasa yang dimilikinya. Berdasarkan teks berita Cnnindonesia.com terlihat mencoba menguatkan kata 'dikotomi' dengan mengangkat kutipan yang dikeluarkan oleh Amien Rais secara langsung. Kemudian dari sinilah diketahui ada kecenderungan Cnnindonesia.com untuk menggali dan mencari padanan kosakata untuk menguatkan kata dikotomi tersebut. Padanan kata yang digunakan untuk menguatkan tersebut disebut sinonim atau persamaan makna kata, dalam hal ini makna dikotomi sama dengan kelompok. Dengan demikian Cnnindonesia.com telah melakukan upaya diskursif dengan berusaha menguatkan kata dikotomi dengan pilihan kata atau diksi yang merujuk pada suatu kelompok orang dalam teks berita.

Pengulangan kosakata dengan kategori makna yang sama tersebut sesuai dengan data yang disebutkan di atas antara lain: partai, kelompok, hizbullah, hizbusy syaithan, anti Tuhan, partai setan, partai Allah. Pengulangan kata yang dsebutkan tersebut secara struktrur kata adalah berbentuk sinonim, yaitu berkmakna kelompok. 


\section{b. Praktik Sosiokultural}

Praktik sosiokultural merupakan hubungan antara analisis tekstual dengan praktik diskursif dari pemberitaan cnnindonesia.com. Jika berdasarkan analisis tekstual maka kata yang muncul sebagai representasi dari dikotomi atau sinonim dalam teks berita adalah dua kutub dan kelompok. Istilah dua kutub ini menggambarkan bahwa partai di Indonesia di bagi menjadi dua yaitu partai setan dan partai Allah.

Pada pemberitaan ini, cnnindonesia.com mencoba untuk menggambarkan maksud dikotomi atas pernyataan Amien Rais dengan kata-kata yang mempunyai maksud setara. Dengan pengulangan ini selain memudahkan pembaca atas maksud pernyataan Amien Rais, sebenarnya cnnindonesia.com juga turut andil dalam bermain yakni berusaha mempengaruhi pembaca untuk membuat opini baru. Sebab apa yang ditulis pada berita langsung mengarah dengan mendasarkan pernyataan yang sepihak dari salah seorang tokoh. Sehingga tak ayal berita tersebut seolah-olah dibuat sebagai bentuk penyerangan terhadap tokoh besar tersebut. Hal ini bisa dilihat dari pola kosakata yang dipilih bersifat melawan seperti bentuk kosakata presiden, ilmunya pas-pasan, rekontruksi, bangsa, kosakata ini seperti sengaja dipilih.

\section{PENUTUP}

Dari hasil temuan dan pembahasan di atas dapat disimpulkan, pemberitaan tentang partai setan dan partai Allah oleh Cnnindonesia.com menggunakan diksi secara dominan pada kata abstrak, kata konkret, kata khusus, dan kata asing dalam penulisannya. Kemudian pada representasi diksi ditemukan pola kosakata yang berulang dan disusun kembali sehingga pola kosakata tersebut seolah ingin menegaskan sesuatu. Adapun penegasan pola kosakata yang dilakukan Cnnindonesia.com dalam teks berita ditemukan pola kosakata bentuk sinonim atau padanan kata. Dengan demikian berdasarkan dari pola kosakata tersebut, berita yang ditulis berupaya ingin menyudutkan 'sesuatu' yang dalam hal ini adalah Amien Rais sebagai tokoh yang menjadi sorotan.

Sebagai bahan yang perlu didiskusikan, pada analisis teks berita Cnnindonesia.com ditemukan pola diksi dalam berita tersebut. Namun, terkait ideologi dari penulis asli berita dan kesamaan terhadap ideologi dengan institusi Cnnindonesia.com belum dilakukan secara mendalam. Penulis hanya berfokus pada sisi aspek ideologi dari sudut pandang teks berita Cnnindonesia.com saja.

\section{Daftar Pustaka}

Assegaf, Dja far. (1991).Jurnalistik Masa Kini. Bandung :PT Remaja Rosdakarya.

Badara, Aris. (2012). Analisis Wacana: Teori, Metode, dan Penerapan pada Wacana Media. Jakarta: Kencana Prenada Media Group.

Darma, Aliah Yoce. (2009). Analisis Wacana Kritis. Bandung: YramaWidya.

Djuraid, Husnun N. (2007). Panduan Menulis Berita : Edisi Revisi. Malang : UMM. Press.

Eriyanto. (2012). Analisis Wacana Kritis: Pengantar Analisis Teks Media. Yogyakarta: LKis Group.

Fairclough, Norman. (1989). Language and Power. London: Longman.

Fairclough, Norman. (1992). Discourse and Text: Linguistic and Intertextual Analysis Within Discousre Analysis. Sage Journal Vol. 3 (2). 193-217. London, New Bury Park and Delhi. 
Fairclough, Norman. (1995). Critical Discourse Analysis: The Critical Study of Language. London and Newyork: Longman Group Limited.

Fairclough, Norman and Ruth Wodak. (1997). Critical Discourse Analysis:and An Overview. Dalam: Teun Van Dijk (Ed). Discourse and Interaction. London: Sage Publication pg. 67-97.

Halliday, M. A. K. (1978). Language as Social Semiotic. London: Edward Arnold.

Junaedi, Fajar. (2007). Komunikasi Massa, Pengantar Teoritis. Yogyakarta: Penerbit Santusta.

Keraf, Gorys. (2010). Diksi dan Gaya Bahasa. Jakarta: Gramedia.

Kurniawan, Agung. (2005). Transformasi Pelayanan Publik. Yogyakarta: Pembaharuan.

Mahsun. (2014). Metode Penelitian Bahasa: Tahapan, Strategi, Metode, dan Tekniknya. Jakarta: PT Grafindo Persada.

Mardikantaro, Hari Bakti. (2014). Analisis Wacana Kritis pada Tajuk Antikorupsi di Surat Kabar Berbahasa Indonesia. Jurnal Litera Vol. 13, Nomor 2. Yogyakarta: FBS UNY.

Mayasari, Nani Darmayanti, Sugeng Riyanto. (2013). Critical Discourse Analysis of Reporting on Saweran for KPK Building in Media Indonesia Daily Newspaper. International Journal of Linguistic, Vol. 5, No.4, Macrothink Institute.

Moleong, L.J. (2013). Metodologi Penelitian Kualitatif: Edisi Revisi. Bandung: Remaja Rosda Karya.

Richardson. (2007). Analysing Newspaper: An Approach from Critical Discourse Analysis. England: Paldrave Macmillan.
Romli, Asep Syamsul M. (2002). Panduan Menjadi Penulis. Bandung : Batic Press \& Tonase Pratama.

Widyamartaya A. (1990). Seni Menuangkan Gagasan.Yogyakarta: Penerbit. Kanisius.

CNN Indonesia. https://id.wikipedia.org/wiki/CNN_Indonesi a diakses pada 24 Mei 2018 
Suar Bétang, Vol.13, No.2, Edisi Desember, 2018: 193-205 